\title{
Distribution Pattern of Metals in Atmospheric Settling Dust along Roads in Kano Metropolis, Nigeria
}

\author{
O. J. Okunola, ${ }^{1}$ A. Uzairu, ${ }^{2}$ S. Uba, ${ }^{2}$ C. S. Ezeanyanaso, ${ }^{3}$ and Y. Alhassan ${ }^{4}$ \\ ${ }^{1}$ Department of Applied Chemistry, Federal University Dutsin-Ma, PMB 5001, Dutsin-Ma, Katsina, Nigeria \\ ${ }^{2}$ Department of Chemistry, Ahmadu Bello University, PMB 810000, Zaria, Nigeria \\ ${ }^{3}$ Textile Division, Federal Institute of Industrial Research Oshodi, PMB 21023, Ikeja, Lagos, Nigeria \\ ${ }^{4}$ National Research Institute for Chemical Technology, PMB 1052, Basawa, Zaria, Nigeria
}

Correspondence should be addressed to O. J. Okunola; okunolaoj@gmail.com

Received 20 August 2014; Revised 18 November 2014; Accepted 23 December 2014

Academic Editor: Tianlong Deng

Copyright (C) 2015 O. J. Okunola et al. This is an open access article distributed under the Creative Commons Attribution License, which permits unrestricted use, distribution, and reproduction in any medium, provided the original work is properly cited.

\begin{abstract}
The sequential extraction of $\mathrm{Cd}, \mathrm{Cr}, \mathrm{Ni}, \mathrm{Pb}, \mathrm{Cu}$, and $\mathrm{Zn}$ in atmospheric dust particles collected along ten high traffic roads in Kano metropolis was carried out. Analyses of metals in the extracts were done using flame atomic absorption spectrometry (FAAS). The samples analyzed for metals indicated high levels of $\mathrm{Cd}, \mathrm{Cr}, \mathrm{Ni}, \mathrm{Pb}, \mathrm{Cu}$, and $\mathrm{Zn}$ in the atmospheric dust samples. The sequential extractions that showed significant amount of $\mathrm{Cd}$ were associated with $\mathrm{CO}_{3}{ }^{2-}$ and $\mathrm{Fe}-\mathrm{MnO}$ fractions especially during the dry seasons. For $\mathrm{Cr}$ and $\mathrm{Ni}$, their occlusion in crystal lattice of the soil fraction exhibited the highest percentage. Pb in the particulate dust samples is significantly associated with the carbonate bound fraction with range of $8.81-64.69 \%$ across the season. The behaviour of $\mathrm{Cu}$ is quite different from other metals in that percentage fractions are higher in the organic bound. As for $\mathrm{Zn}$, significant amounts were associated with the residue fractions ranging from 0.96 to $87.50 \%$ across the seasons. This study revealed contamination of the particulate dust with $\mathrm{Cd}$ and $\mathrm{Pb}$; this implies health risks to human, living or carrying out daily activities along the corridors of these roads.
\end{abstract}

\section{Introduction}

The increase of health problems related to road dust arising from urbanization and industrialization has especially during the last two centuries gradually created a demand for more efficient vehicle-associated emission controls. According to Cho et al. [1], $50 \%$ of urban air particulate emissions are closely related to road traffic [1]. Studies have also reported association between traffic density, closeness to roads, and various respiratory symptoms in children [1-3].

From literature, motor vehicles are known to introduce a number of toxic metals into the atmosphere, which are later deposited on roadsides [4]. As a result of vehicle emissions, the deposition of heavy metals on the road may result in their incorporation into dust due to their size that ranges between $10^{-9}$ and $10^{-6} \mathrm{~m}$ [5]. Of all the types of dust found in the urban environment, one of the most highly toxic metals is dust from road. Since such dust may be inhaled via airborne or discharged into rivers by storm-water wash-off, dust from road may hence represent a major pollution source within the urban environment [6]. These activities release dust particulate which adversely affects human. Therefore, monitoring of particulate matter especially with heavy metals is imperative.

Based on the above facts, the present study aims to assess the distribution of metals $(\mathrm{Cd}, \mathrm{Cr}, \mathrm{Ni}, \mathrm{Pb}, \mathrm{Cu}$, and $\mathrm{Zn}$ ) species in atmospheric settling dust along roads using sequential extraction.

\section{Materials and Methods}

2.1. Study Area. Kano Metropolis is located between latitudes $11^{\circ} 59^{\prime} 59.57$ and $12^{\circ} 02^{\prime} 39.57^{\circ} \mathrm{N}$ of the equator and between longitudes $8^{\circ} 33^{\prime} 19.69$ and $8^{\circ} 31^{\prime} 59.69^{\circ} \mathrm{E}$. The climate of the Kano is dominated by the migration of the intertropical convergence zone. Industrially, it is one of the most developed cities in Northern Nigeria, and tannery and textile 


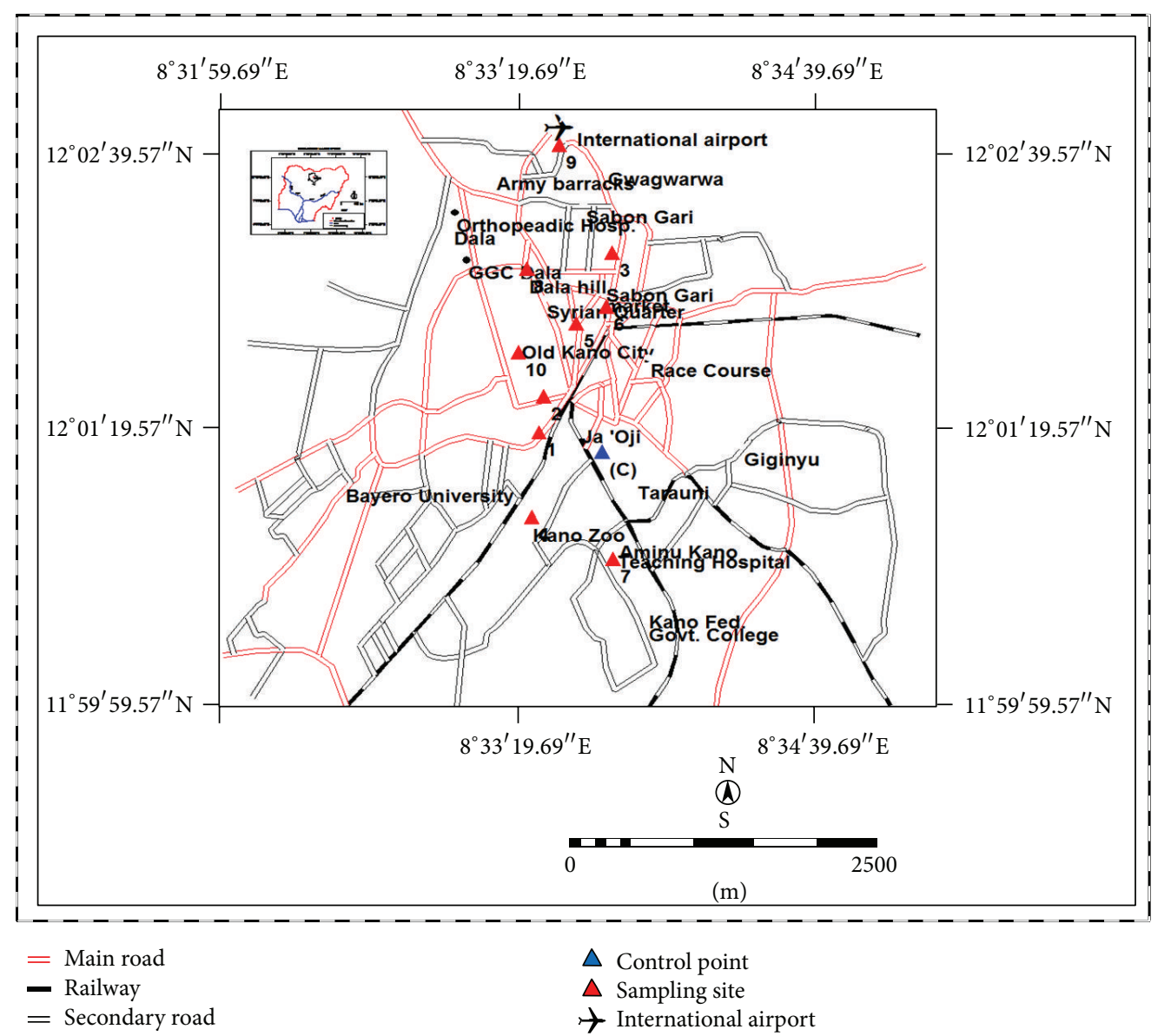

FIGURE 1: Kano Metropolis showing the sampling sites. Source: adapted and modified from Google Map Data, 2010.

are some of its dominating industries [7]. Kano Metropolis attracts substantial number of immigrants being the seat of government and center of commerce, industry, and education. In the city, there are various large markets such as the City (Kurmi) Market, Sabon Gari Market, and Katin Kwari (cloth market) which attract people from all over the country. The major form of transportation within Kano Metropolis is by road. Most common transport modes used include cars, buses, motorcycles, and tricycles (Keke NAPEP).

2.2. Sample Collection and Pretreatment. Sampling of dusts for this study was conducted from December 2009 to September 2010 across four named seasons; cold and dry, hot and dry, warm and wet, and warm and dry. The criteria for selections of roads for the study were based on foreknowledge of the relative traffic density on each road and the desire to have each category of traffic density in different sections of the Metropolis. Samples were collected from 10 roadside locations (1-10) and a control site (C) all over the Metropolis as shown in Figure 1. These sites were mainly located in residential and commercial areas of the metropolis. Control samples were obtained from a small garden within a residential buildup area of farm center, which is not closer to any secondary or main road. Average temperature across the seasons is $31.5-36.6^{\circ} \mathrm{C}, 30.0-39.1^{\circ} \mathrm{C}, 30.5-33.9^{\circ} \mathrm{C}$, and $30.1-$ $39.5^{\circ} \mathrm{C}$, respectively.

Atmospherically deposited particulates were sampled according to indirect method of air sampling described by Nabuloa [8]. Similarly, the traffic density was determined by manual counting according to Okunola et al. [9] as shown in Table 1.

2.3. Quality Assurance. All apparatus including glassware and plastic tubes were sterilized according to Adnan et al. [10]. All reagents used were of analytical grade, and the instrument working calibration was made by diluting the commercial Scharlau Japan stock solution $\left(1000 \mathrm{mg} \mathrm{L}^{-1}\right)$ standard with distilled-deionized water. The detection limits for metal analysis were $0.01 \mathrm{mg} \mathrm{L}^{-1}$ for $\mathrm{Cd}, \mathrm{Cr}, \mathrm{Cu}, \mathrm{Ni}$, and $\mathrm{Pb}$ and $0.05 \mathrm{mg} \mathrm{L}^{-1}$ for $\mathrm{Zn}$.

2.4. Metal Extraction of Atmospheric Settling Dust. Total metal assessmentwas done according to Ogunfowokan et al. [6], while sequential extraction was done using Finžgar et al. [11] method. The method modified Tessier et al. [12] method. 
TABLE 1: Mean traffic density/hour.

\begin{tabular}{|c|c|c|c|c|c|}
\hline \multirow{2}{*}{ Sampling site code } & \multirow{2}{*}{ Sampling site } & \multicolumn{4}{|c|}{ Average traffic volume per hr } \\
\hline & & Number of motorcycles & Number of vehicles & Number of trucks/lorries & Total \\
\hline 1 & Aminu Kano & $1902 \pm 12$ & $2634 \pm 10$ & $196 \pm 2$ & 4732 \\
\hline 2 & Zoo & $2011 \pm 20$ & $1504 \pm 8$ & $121 \pm 5$ & 3636 \\
\hline 3 & Dan Agundi & $1206 \pm 15$ & $1935 \pm 12$ & $216 \pm 2$ & 2831 \\
\hline 4 & Kofar Nassarawa & $1323 \pm 13$ & $1801 \pm 19$ & $46 \pm 2$ & 3170 \\
\hline 5 & Rimi Market & $3005 \pm 10$ & $2008 \pm 14$ & $25 \pm 2$ & 5038 \\
\hline 6 & Sani Abacha & $6857 \pm 23$ & $1292 \pm 13$ & $207 \pm 2$ & 8357 \\
\hline 7 & Ibo Road & $2464 \pm 19$ & $1845 \pm 19$ & $35 \pm 5$ & 4344 \\
\hline 8 & Court/France & $2651 \pm 18$ & $1041 \pm 9$ & $16 \pm 2$ & 3708 \\
\hline 9 & Kofar Mazugal & $1995 \pm 21$ & $2836 \pm 12$ & $149 \pm 2$ & 4180 \\
\hline 10 & Zungeru/Airport & $1443 \pm 11$ & $2366 \pm 17$ & $198 \pm 3$ & 4007 \\
\hline $\mathrm{C}$ & Farm Center & Nil & Nil & Nil & Nil \\
\hline
\end{tabular}

TABLE 2: Concentrations $\left(\mu \mathrm{gg}^{-1}\right)$ of metals in samples collected from different sites across the seasons.

\begin{tabular}{|c|c|c|c|c|c|c|c|c|c|c|c|c|}
\hline \multirow{2}{*}{ Metal } & \multirow{2}{*}{ SN } & \multicolumn{10}{|c|}{ Site } & \multirow{2}{*}{ Control } \\
\hline & & 1 & 2 & 3 & 4 & 5 & 6 & 7 & 8 & 9 & 10 & \\
\hline \multirow{4}{*}{$\mathrm{Cd}$} & A & 4.89 & 5.74 & 2.89 & 10.80 & 10.49 & 8.9 & 6.68 & 13.93 & 8.77 & 12.88 & 0.00 \\
\hline & B & 9.49 & 10.81 & 5.27 & 20.39 & 18.84 & 15.38 & 11.89 & 26.00 & 15.27 & 19.70 & 0.00 \\
\hline & $\mathrm{C}$ & 12.01 & 13.58 & 7.06 & 24.82 & 25.18 & 19.55 & 14.92 & 32.95 & 20.72 & 25.85 & 0.00 \\
\hline & $\mathrm{D}$ & 2.76 & 3.39 & 1.53 & 7.59 & 6.86 & 6.43 & 5.30 & 8.81 & 5.59 & 8.69 & 0.00 \\
\hline \multirow{4}{*}{$\mathrm{Cr}$} & A & 19.78 & 36.96 & 61.28 & 33.89 & 29.53 & 20.00 & 24.67 & 38.85 & 87.79 & 28.14 & 0.00 \\
\hline & B & 19.78 & 56.57 & 44.50 & 47.79 & 29.96 & 42.13 & 47.07 & 171.46 & 151.82 & 52.92 & 0.01 \\
\hline & $\mathrm{C}$ & 24.57 & 70.98 & 98.28 & 66.85 & 36.90 & 43.69 & 67.62 & 220.76 & 188.52 & 64.94 & 0.00 \\
\hline & $\mathrm{D}$ & 8.74 & 27.61 & 22.06 & 21.55 & 19.95 & 16.80 & 19.96 & 72.58 & 67.94 & 20.73 & 0.00 \\
\hline \multirow{4}{*}{$\mathrm{Ni}$} & A & 134.75 & 71.91 & 80.67 & 66.83 & 90.69 & 79.82 & 66.88 & 72.88 & 46.54 & 121.14 & 0.01 \\
\hline & B & 236.61 & 34.66 & 43.73 & 26.27 & 72.29 & 49.89 & 129.13 & 183.88 & 64.80 & 86.65 & 0.00 \\
\hline & C & 327.14 & 47.98 & 53.85 & 37.63 & 99.67 & 88.86 & 196.65 & 237.54 & 94.64 & 121.52 & 0.00 \\
\hline & $\mathrm{D}$ & 254.85 & 38.81 & 47.55 & 38.00 & 47.10 & 35.96 & 166.95 & 172.69 & 89.50 & 74.78 & 0.00 \\
\hline \multirow{4}{*}{$\mathrm{Pb}$} & A & 133.71 & 167.49 & 189.05 & 129.13 & 188.89 & 156.77 & 215.39 & 213.76 & 161.23 & 219.52 & 0.00 \\
\hline & B & 90.35 & 135.22 & 151.23 & 218.58 & 1068.01 & 118.97 & 137.60 & 135.06 & 143.22 & 164.08 & 0.00 \\
\hline & $\mathrm{C}$ & 127.53 & 182.75 & 196.28 & 291.10 & 1408.57 & 178.77 & 253.69 & 247.86 & 197.24 & 254.98 & 0.00 \\
\hline & $\mathrm{D}$ & 61.59 & 80.89 & 95.18 & 121.79 & 640.68 & 75.80 & 78.12 & 78.62 & 86.52 & 101.98 & 0.00 \\
\hline \multirow{4}{*}{$\mathrm{Cu}$} & A & 26.51 & 50.71 & 44.51 & 55.10 & 56.21 & 71.54 & 131.64 & 36.71 & 36.59 & 37.44 & 0.00 \\
\hline & B & 16.15 & 39.16 & 40.21 & 205.21 & 57.34 & 61.95 & 116.76 & 31.66 & 30.54 & 25.05 & 0.00 \\
\hline & $\mathrm{C}$ & 20.54 & 53.87 & 51.28 & 267.39 & 66.32 & 81.84 & 149.28 & 41.05 & 40.19 & 31.47 & 0.00 \\
\hline & $\mathrm{D}$ & 13.30 & 23.91 & 21.51 & 98.62 & 31.72 & 36.70 & 64.79 & 17.71 & 18.25 & 16.61 & 0.00 \\
\hline \multirow{4}{*}{$\mathrm{Zn}$} & A & 153.98 & 295.82 & 259.85 & 507.07 & 429.23 & 372.08 & 192.13 & 2028.42 & 675.45 & 213.49 & 0.10 \\
\hline & B & 2312.28 & 11711.20 & 2371.19 & 10892.70 & 9435.83 & 7999.74 & 5694.99 & 23515.52 & 14673.83 & 7405.33 & 0.28 \\
\hline & $\mathrm{C}$ & 2083.70 & 8781.65 & 2263.52 & 8451.63 & 7135.12 & 6354.11 & 4932.63 & 17401.77 & 11204.80 & 5506.89 & 0.28 \\
\hline & $\mathrm{D}$ & 211.52 & 1261.07 & 201.82 & 1211.31 & 883.05 & 741.49 & 608.18 & 3152.32 & 1493.91 & 770.06 & 0.32 \\
\hline
\end{tabular}

SN: season; A: cool and dry season; B: hot and dry season; C: warm and wet season; D: warm and dry season.

\section{Results and Discussion}

The total concentrations of $\mathrm{Cd}, \mathrm{Cr}, \mathrm{Ni}, \mathrm{Pb}, \mathrm{Cu}$, and $\mathrm{Zn}$ for the samples are presented in Table 2. In each case the presented value is a mean observed in three determinations. Analysis of variance revealed significant difference $(P<0.05)$ in the contents of the studied heavy metals across sites across the studied seasons. The concentrations across the seasons varied to great extent among the samples: $5.05-25.99,7.01-32.90,1.57-8.72$, and $2.77-$ $13.86{\mu \mathrm{gg}^{-1}}^{-1}$ for Cd; $19.57-171.43,24.14-220.51,8.48-72.16$, and 19.55-87.57 $\mathrm{ggg}^{-1}$ for $\mathrm{Cr}$; 26.54-235.21, 37.36-325.29, 38.00254.70, and 66.67-134.50 $\mathrm{ggg}^{-1}$ for Ni; 90.71-1067.03, 127.05$1408.13,61.19-641.36$, and $133.42-213.52 \mu \mathrm{gm}^{-2}$ for $\mathrm{Pb} ; 15.80-$ 204.73, 20.09-269.77, 13.60-99.24, and 26.02-133.27 $\mu^{-1}$ for $\mathrm{Cu}$; and 2314.36-23531.03, 2087.39-17403.54, 213.04-3154.65, and $154.95-2029.84 \mu_{g g^{-1}}$ for $\mathrm{Zn}$ for cool and dry season, 


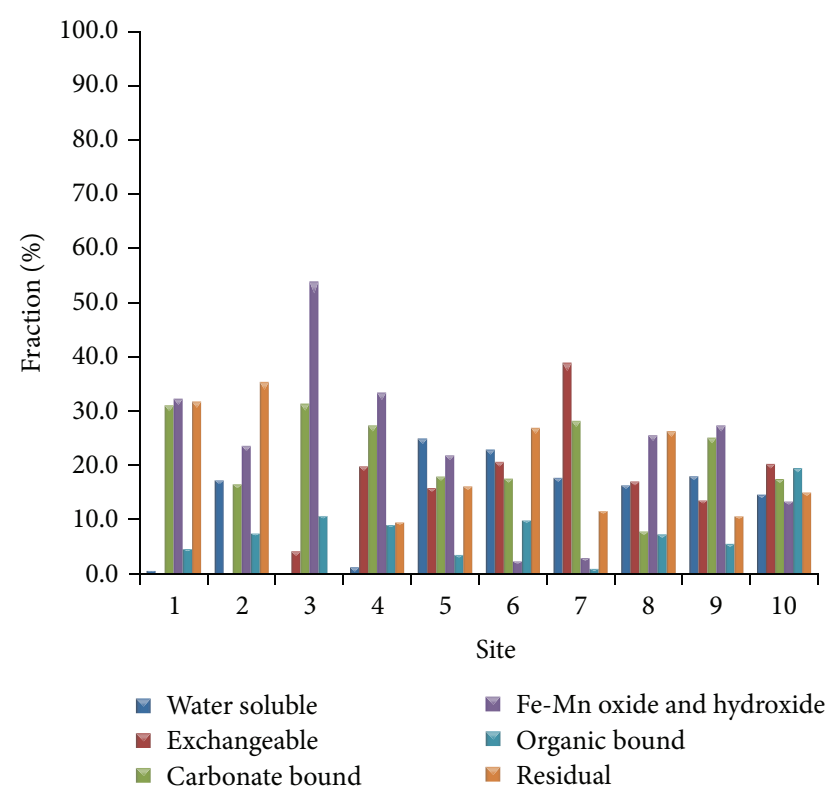

Figure 2: Percentage of $\mathrm{Cd}$ in each operational fraction of atmospheric particulate dust (cool and dry season).

hot and dry season, warm and wet season, and warm and dry season, respectively. Irrespective of sampling site, the distribution of total metals in the atmospheric particulate dust samples generally followed the order: $\mathrm{Cd}<\mathrm{Cr}<\mathrm{Cu}$ $<\mathrm{Ni}<\mathrm{Pb}<\mathrm{Zn}$. Highest concentration of $\mathrm{Cd}, \mathrm{Cr}$, and $\mathrm{Zn}$ was found in site 8 , while highest concentration of $\mathrm{Ni}, \mathrm{Pb}$, and $\mathrm{Cu}$ was found in sites 1,5 , and 4 , respectively. Also, highest concentrations of all studied metals were recorded in hot and dry season with exception of $\mathrm{Zn}$ that has highest concentration recorded in cool and dry season. In general, highest concentrations of metals studied were recorded in dry seasons. This could be due to low moisture content of samples during this season. Comparing the data of control site to the studied sites, lower concentrations of metals were obtained from control site.

Correlation analysis indicates positive significant correlation $(P<0.05)$ between $\mathrm{Zn}$ and $\mathrm{Cr}$ (hot and dry season), and $\mathrm{Zn}$ : $\mathrm{Cd}$ and $\mathrm{Cr}$ (warm and wet season, and warm and dry season). Positive correlation of metals indicates common source of metals.

The distribution of heavy metals $\mathrm{Cd}, \mathrm{Cr}, \mathrm{Ni}, \mathrm{Pb}, \mathrm{Cu}$, and $\mathrm{Zn}$ in the six fractions, water soluble (FI), exchangeable (FII), carbonate bound (FIII), Fe-Mn oxide (FIV), organic bound (FV), and residual (FVI), for all studied samples is summarized in Figures 2-24. The results obtained showed that the amounts of heavy metals extracted from each fraction vary widely among the sites across seasons $(P<$ 0.05).

Significant amount of $\mathrm{Cd}$ was associated with carbonate and Fe-Mn oxide fractions especially during the dry seasons as shown in Figures 2-5. Highest percentage of Fe-Mn oxide was obtained in site 3 during the warm and wet season. Averagely, Cd distribution among the geochemical fractions of the particulate dust in the four seasons was

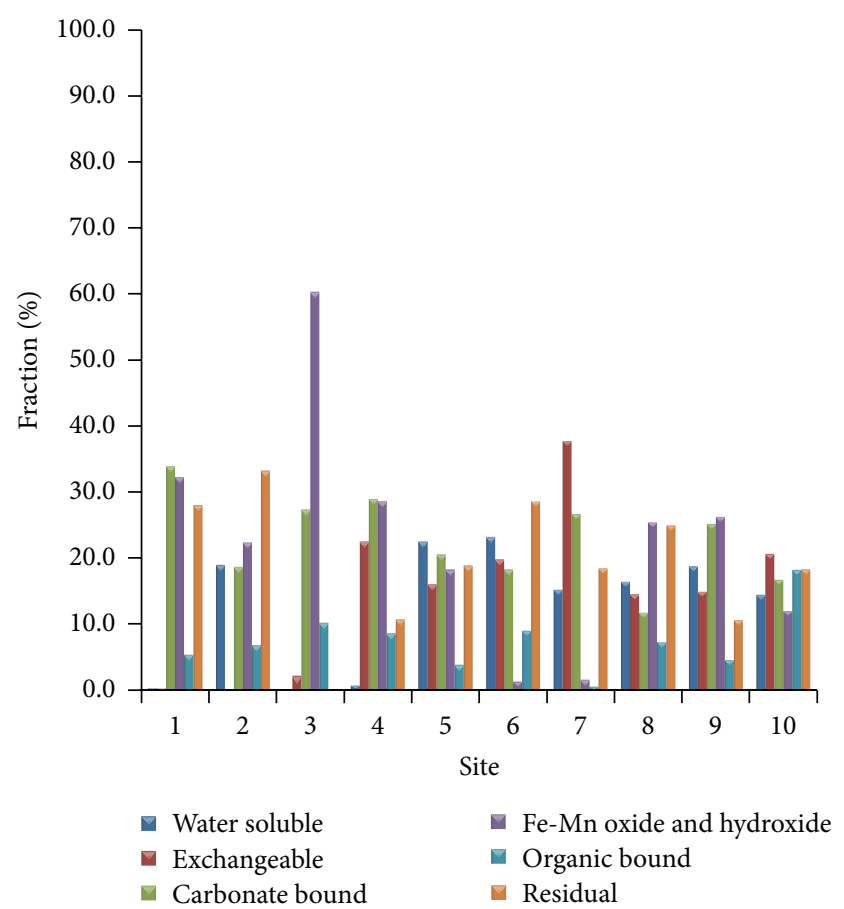

FIgURE 3: Percentage of $\mathrm{Cd}$ in each operational fraction of atmospheric particulate dust (hot and dry season).

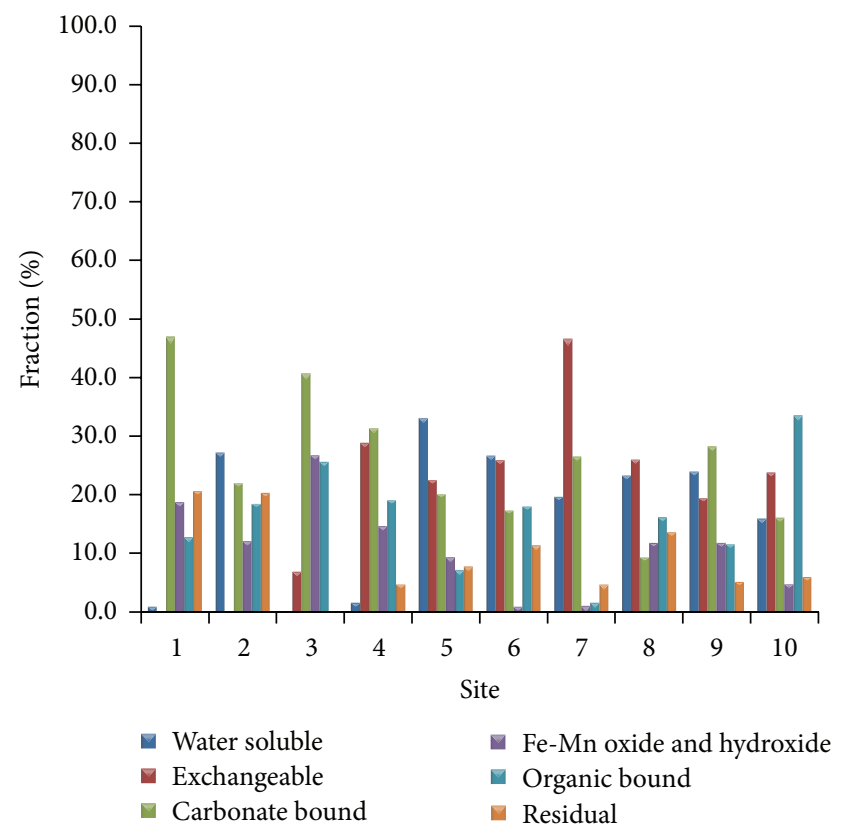

FIgURE 4: Percentage of $\mathrm{Cd}$ in each operational fraction of atmospheric particulate dust (warm and wet season).

cool and dry season: FIV $>$ FIII $>$ FVI $>$ FII $>$ FI $>$ FV, hot and dry season: FIV $>$ FIII $>$ FVI $>$ FII $>$ FI $>$ FV, warm and wet season: FIII $>$ FII $>$ FIV $>$ FV $>$ FI $>$ FVI, 


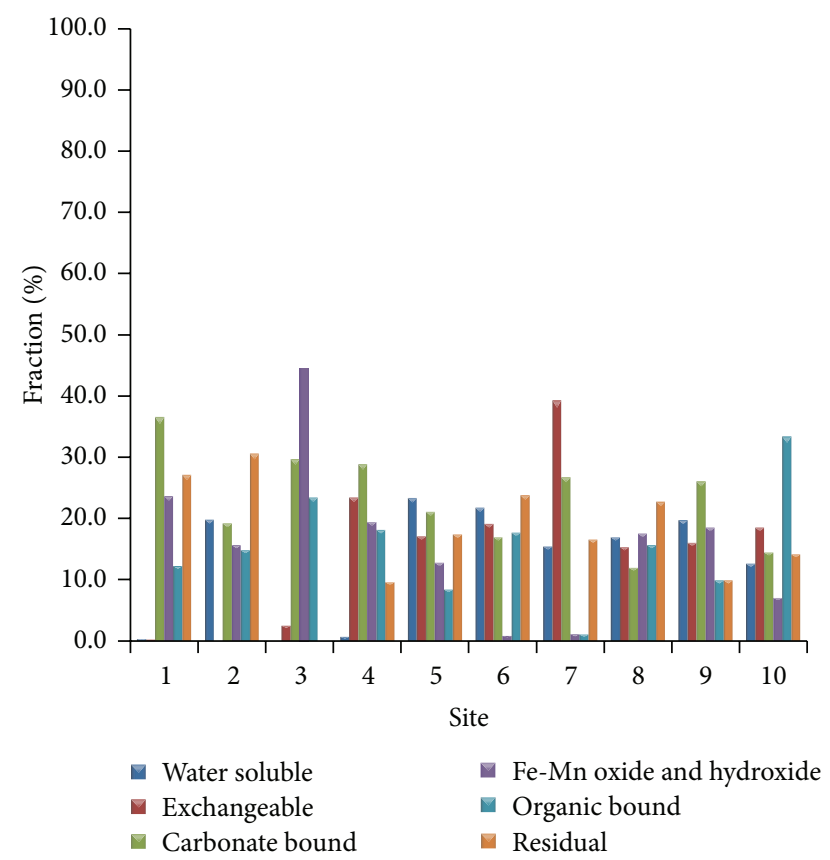

Figure 5: Percentage of $\mathrm{Cd}$ in each operational fraction of atmospheric particulate dust (warm and dry season).

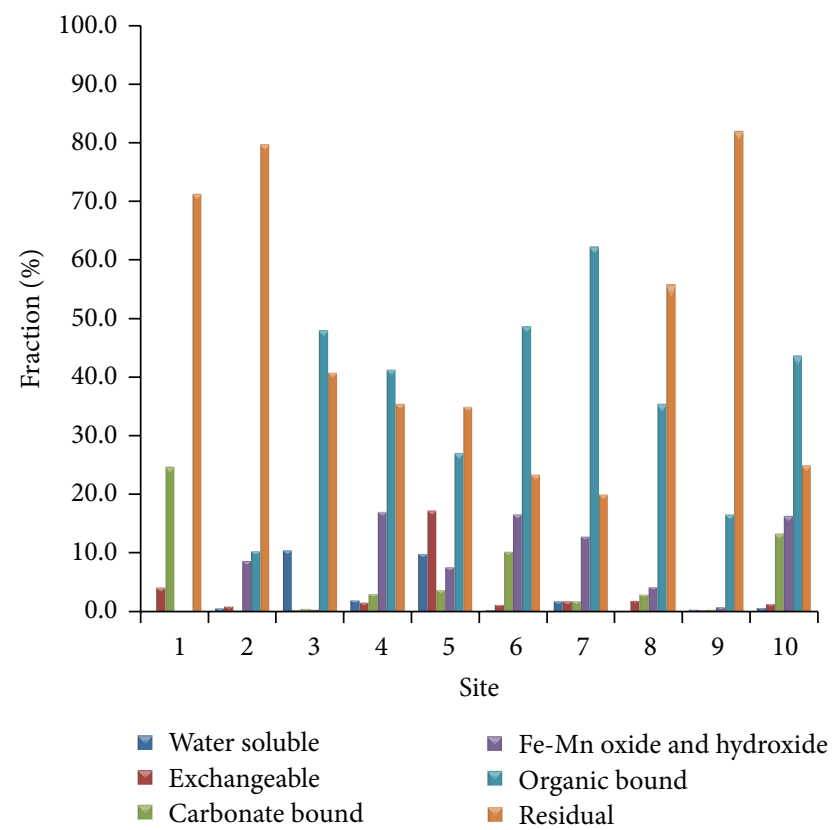

Figure 6: Percentage of $\mathrm{Cr}$ in each operational fraction of atmospheric particulate dust (cool and dry season).

warm and dry season: FIII $>$ FVI $>$ FIV $>$ FV $>$ FII $>$ FI.

For $\mathrm{Cr}$ (Figures 6-9), the residual fraction exhibited the highest percentage ranging from 82.07 to $92.78 \%$ in site 9 in dry season. The low level of $\mathrm{Cr}$ in water soluble and exchangeable fractions of the samples may be an indication that leaching of $\mathrm{Cr}$ from the particulate dust may not occur

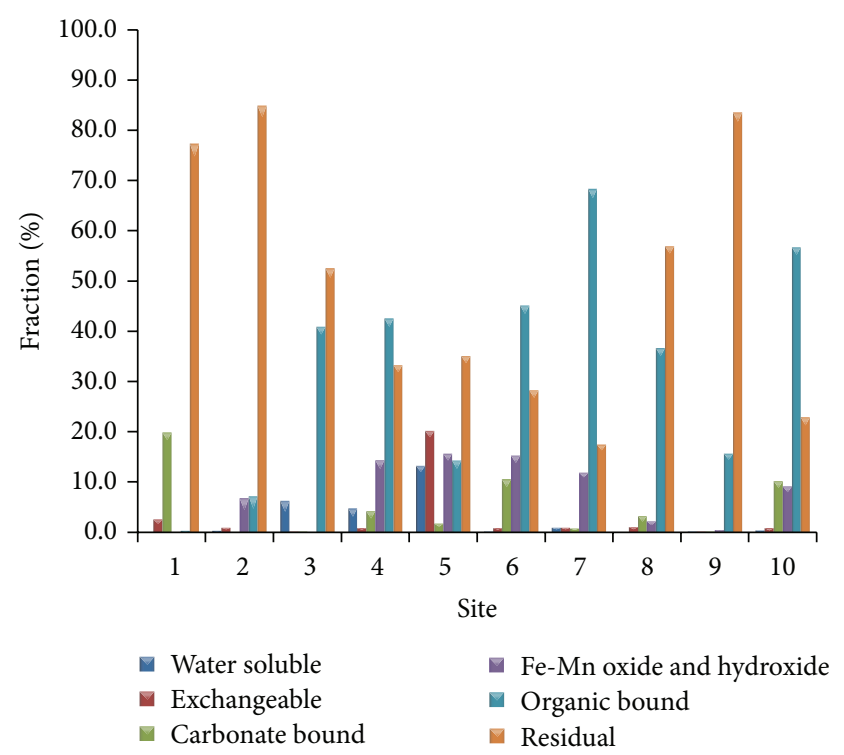

FIgURE 7: Percentage of $\mathrm{Cr}$ in each operational fraction of atmospheric particulate dust (hot and dry season).

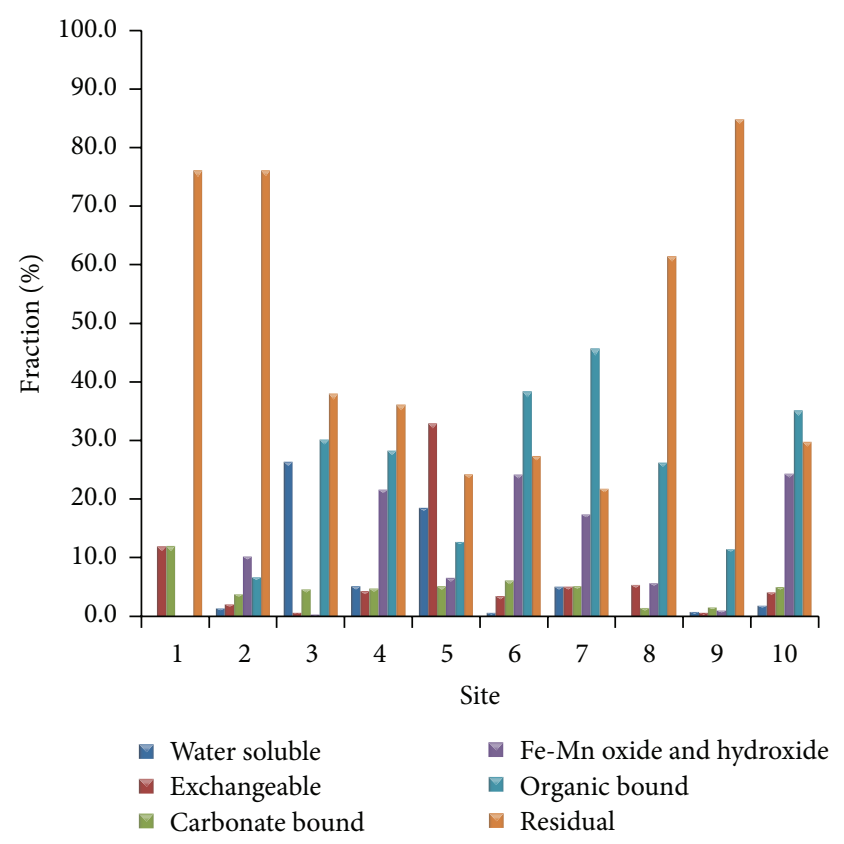

Figure 8: Percentage of $\mathrm{Cr}$ in each operational fraction of atmospheric particulate dust (warm and wet season).

readily. The patterns of $\mathrm{Cr}$ distribution among the fractions of the atmospheric particulate dust in the four seasons are

cool and dry season: FVI $>$ FV $>$ FIV $>$ FIII $>$ FII $>$ FI,

hot and dry season: FVI $>$ FV $>$ FIV $>$ FIII $>$ FII $>$ FI, warm and wet season: $\mathrm{FVI}>\mathrm{FV}>\mathrm{FIV}>\mathrm{FII}>\mathrm{FI}>$ FIII,

warm and dry season: FIII $>$ FVI $>$ FIV $>$ FV $>$ FII $>$ FI. 


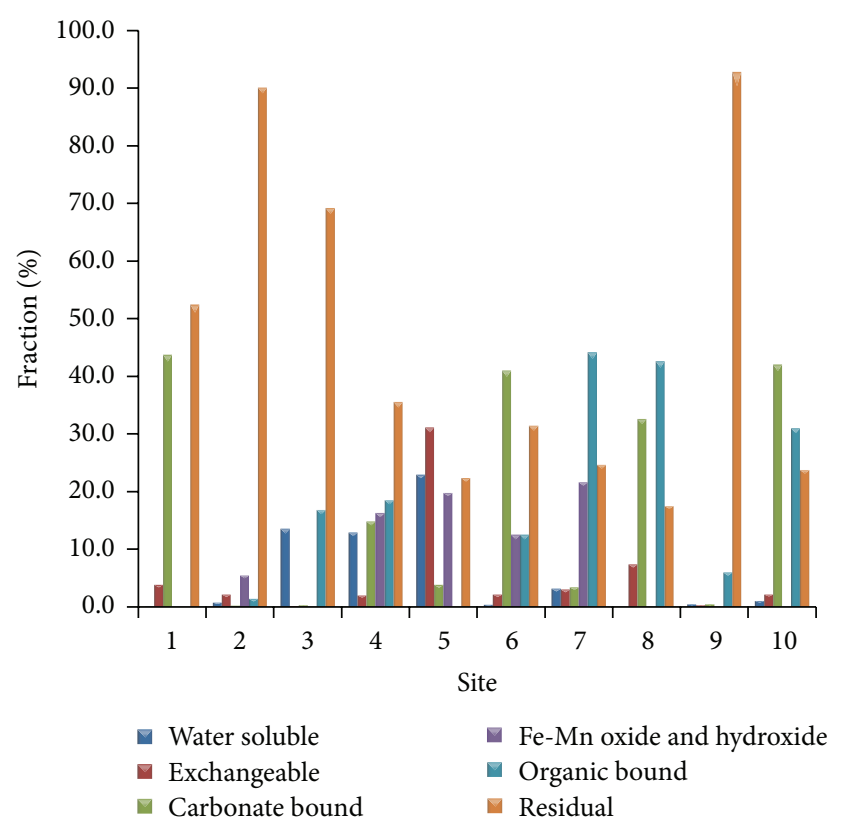

Figure 9: Percentage of $\mathrm{Cr}$ in each operational fraction of atmospheric particulate dust (warm and dry season).

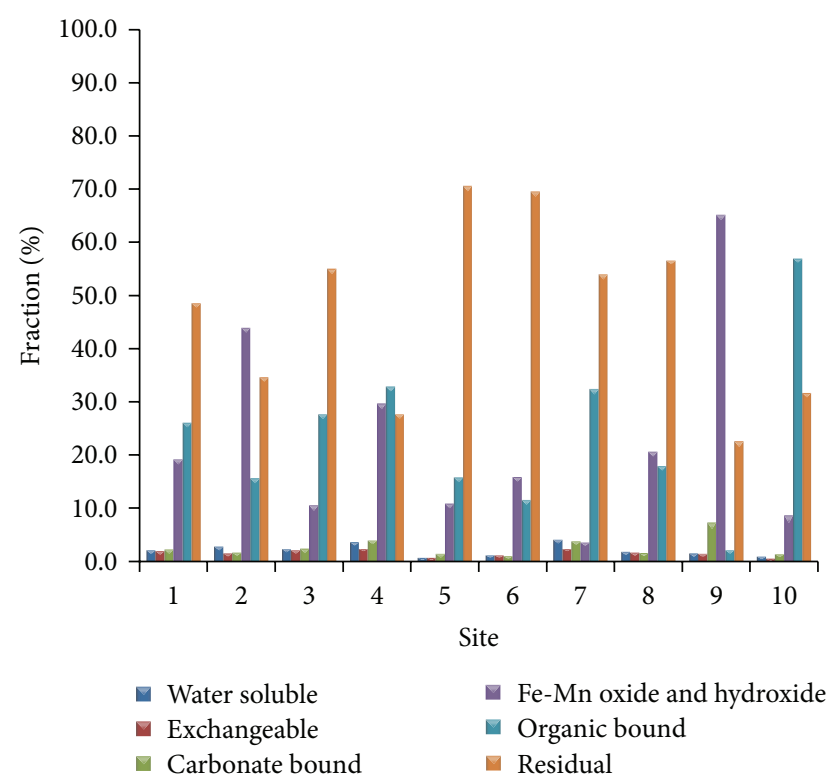

FIgURE 10: Percentage of Ni in each operational fraction of atmospheric particulate dust (cool and dry season).

The Ni similar to $\mathrm{Cr}$ was concentrated in the residual fraction with exception of warm and wet season as shown in Figures 10-13, ranging from 7.62 to $72.73 \%$. The organic fraction was second in proportion ranging from 0.00 to $56.92 \%$, followed by Fe-Mn oxide, carbonate, exchangeable, and water soluble. Based on the result found, the profile obtained for Ni was

cool and dry season: FVI $>$ FV $>$ FIV $>$ FIII $>$ FII $>$ FI,

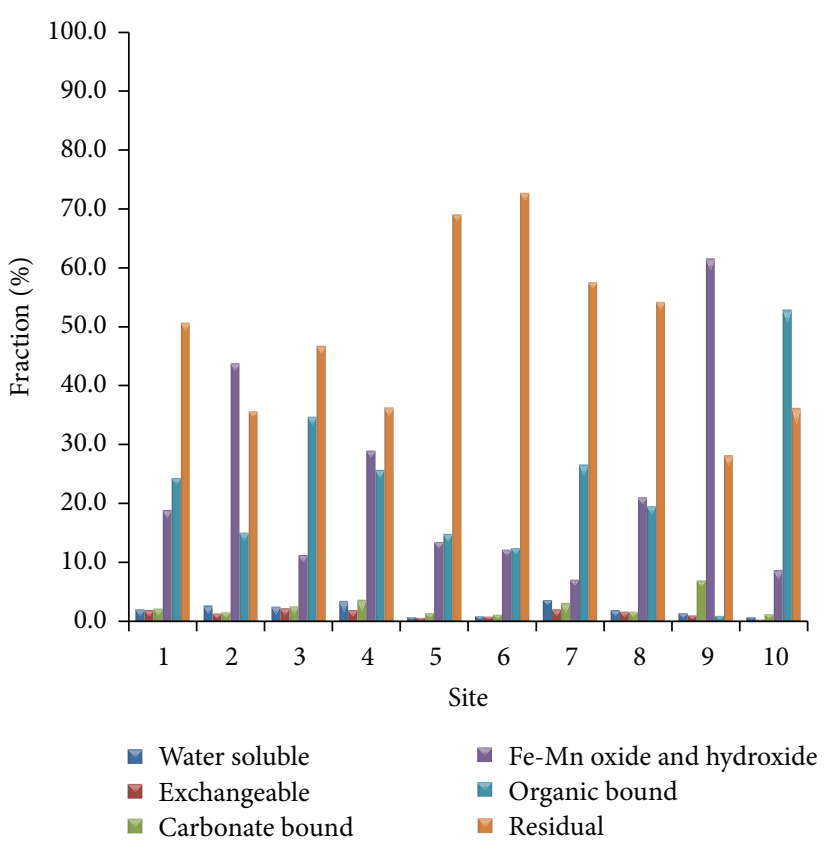

FIGURE 11: Percentage of Ni in each operational fraction of atmospheric particulate dust (hot and dry season).

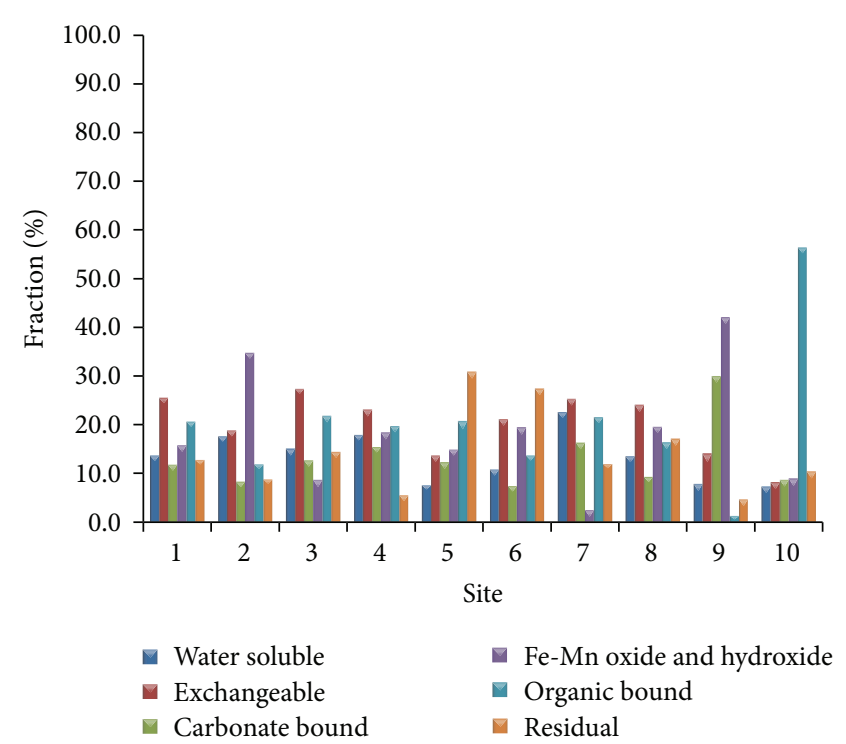

FIGURE 12: Percentage of $\mathrm{Ni}$ in each operational fraction of atmospheric particulate dust (warm and wet season).

hot and dry season: FVI $>$ FV $>$ FIV $>$ FIII $>$ FI $>$ FII, warm and wet season: $\mathrm{FV}>\mathrm{FII}>\mathrm{FIV}>\mathrm{FVI}>\mathrm{FI}>$ FIII,

warm and dry season: FVI $>$ FIV $>$ FIII $>$ FV $>$ FI $>$ FII.

$\mathrm{Pb}$ in the particulate dust samples is significantly associated with the carbonate bound fraction with range of 8.8164.69\% across the season as shown in Figures 14-17, which suggested that $\mathrm{Pb}$ had a preference for carbonate fractions at 


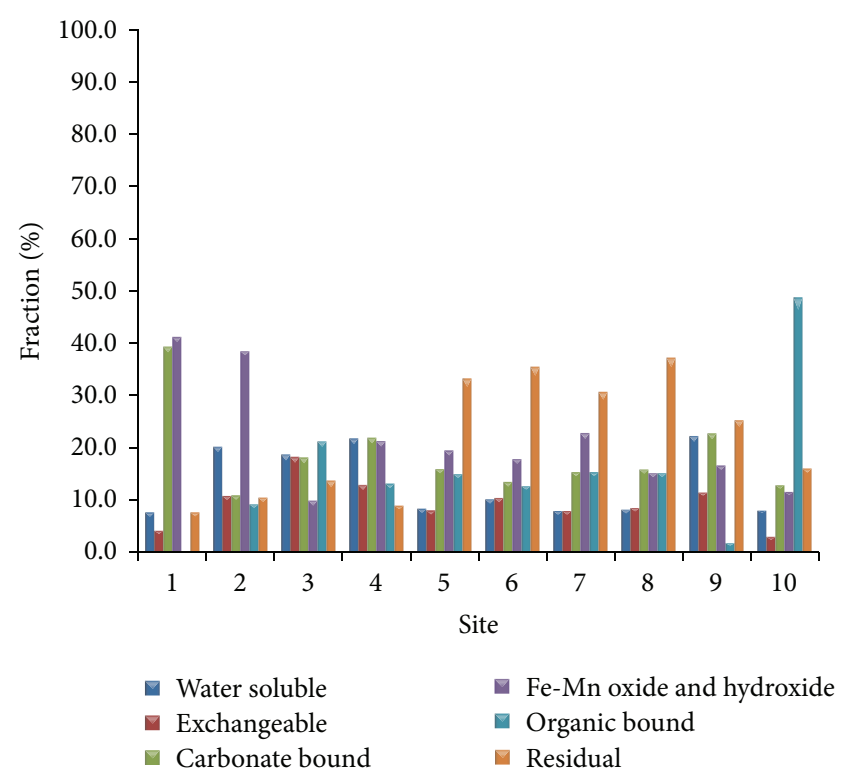

FIGURE 13: Percentage of $\mathrm{Ni}$ in each operational fraction of atmospheric particulate dust (warm and dry season).

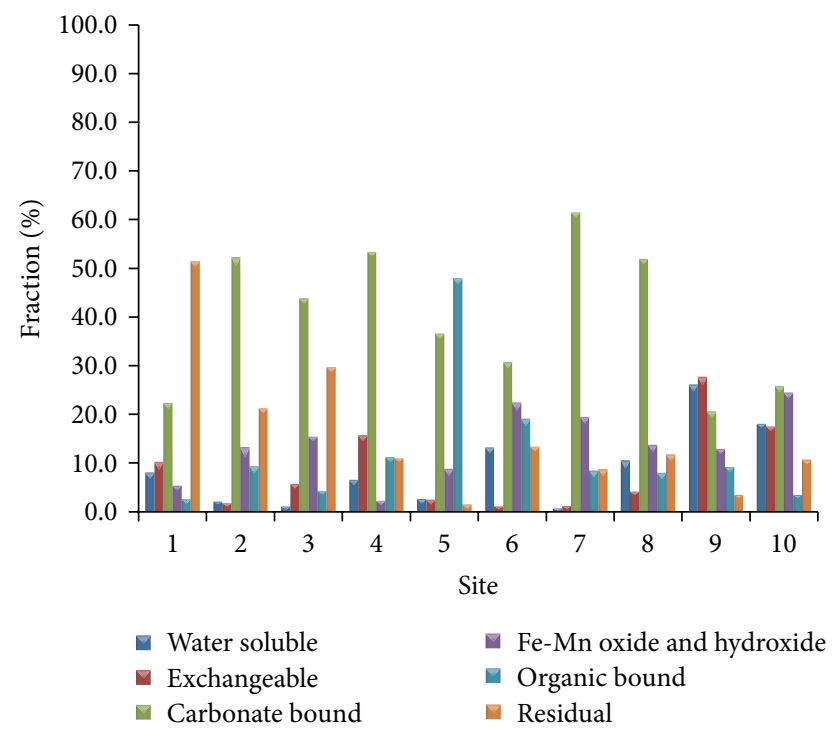

Figure 14: Percentage of $\mathrm{Pb}$ in each operational fraction of atmospheric particulate dust (cool and dry season).

the expense of Fe-Mn oxides. Of the ten samples, site 1 sample has high fraction of $\mathrm{Pb}$ in the residual fraction. However, on the average percent of total $\mathrm{Pb}$ associated with different fractions across the site was in the following order:

cool and dry season: FIII $>$ FVI $>$ FIV $>$ FV $>$ FI $>$ FII,

hot and dry season: FIII $>$ FVI $>$ FIV $>$ FV $>$ FI $>$ FII, warm and wet season: FIII $>$ FVI $>$ FIV $>$ FV $>$ FI $>$ FII,

warm and dry season: FIII $>$ FVI $>$ FIV $>$ FV $>$ FII $>$ FI.

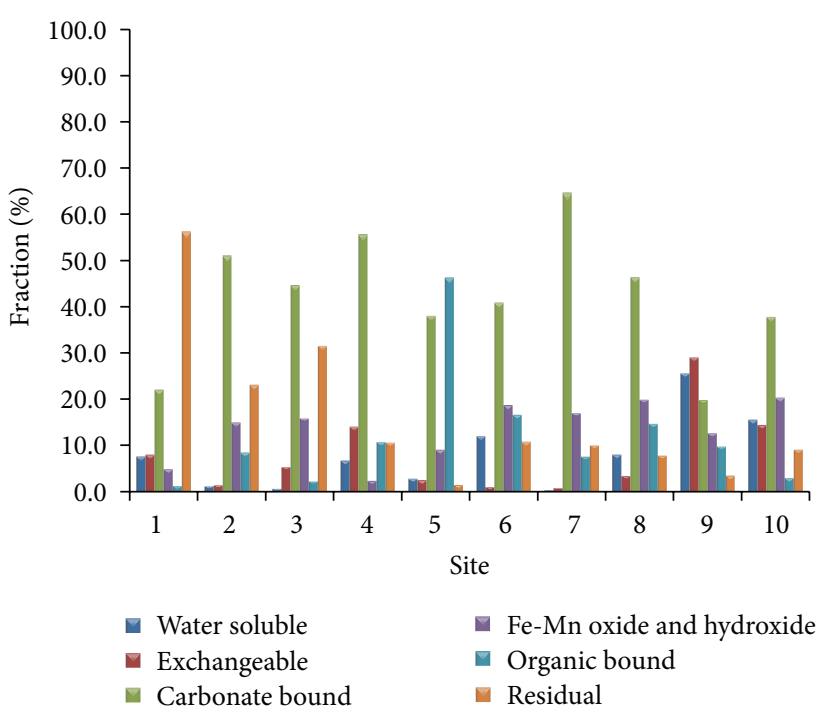

FIgURE 15: Percentage of $\mathrm{Pb}$ in each operational fraction of atmospheric particulate dust (hot and dry season).

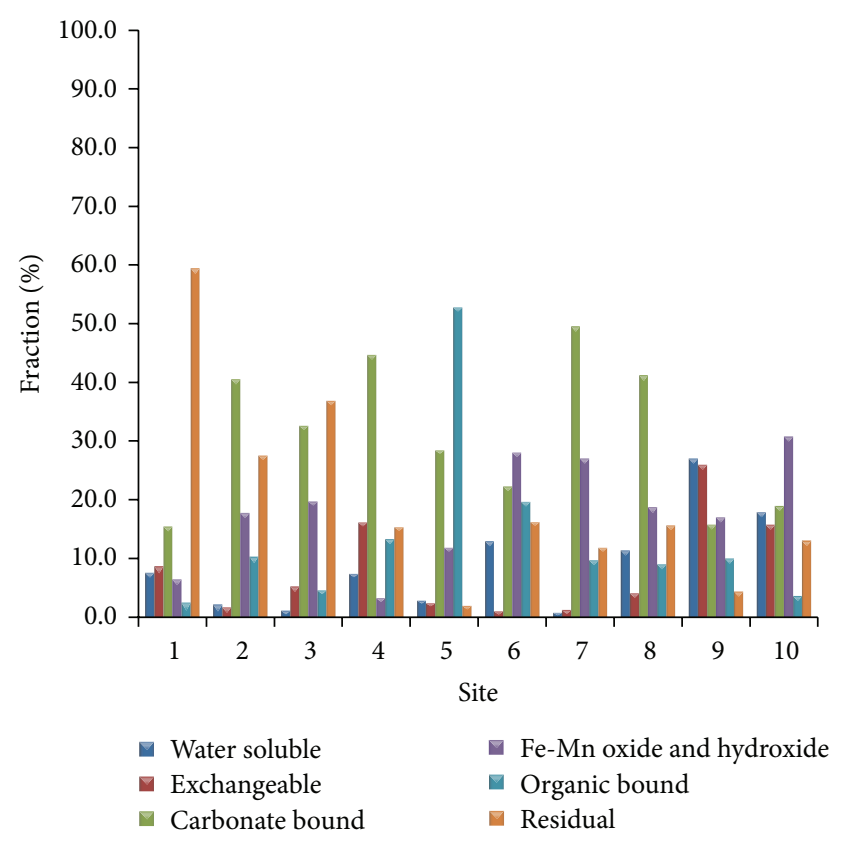

Figure 16: Percentage of $\mathrm{Pb}$ in each operational fraction of atmospheric particulate dust (warm and wet season).

The behaviour of $\mathrm{Cu}$ is quite different from other metals in that percentage fractions are higher in the organic bound ranging from 3.62 to $89.62 \%$ (Figures $18-21$ ). Based on the result found, the profile obtained for $\mathrm{Cu}$ was

cool and dry season: $\mathrm{FV}>\mathrm{FVI}>\mathrm{FIV}>\mathrm{FI}>\mathrm{FII}>\mathrm{FIII}$, hot and dry season: FV $>$ FVI $>$ FIV $>$ FI $>$ FII $>$ FIII, warm and wet season: $\mathrm{FV}>\mathrm{FVI}>\mathrm{FIV}>\mathrm{FI}>\mathrm{FIII}>$ FII,

warm and dry season: FV $>$ FVI $>$ FIV $>$ FI $>$ FIII $>$ FII. 


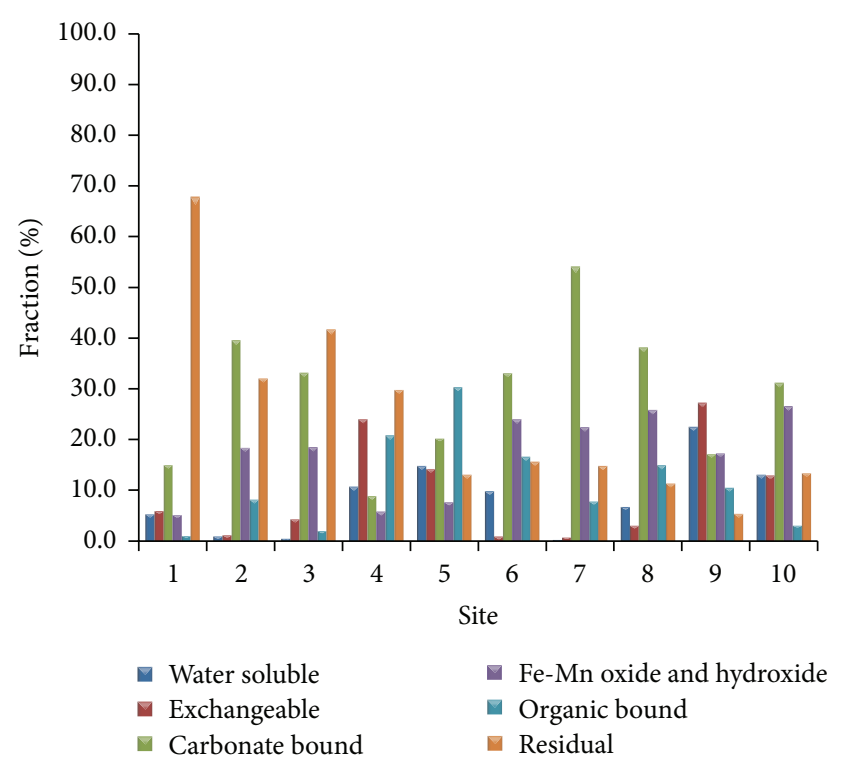

Figure 17: Percentage of $\mathrm{Pb}$ in each operational fraction of atmospheric particulate dust (warm and dry season).

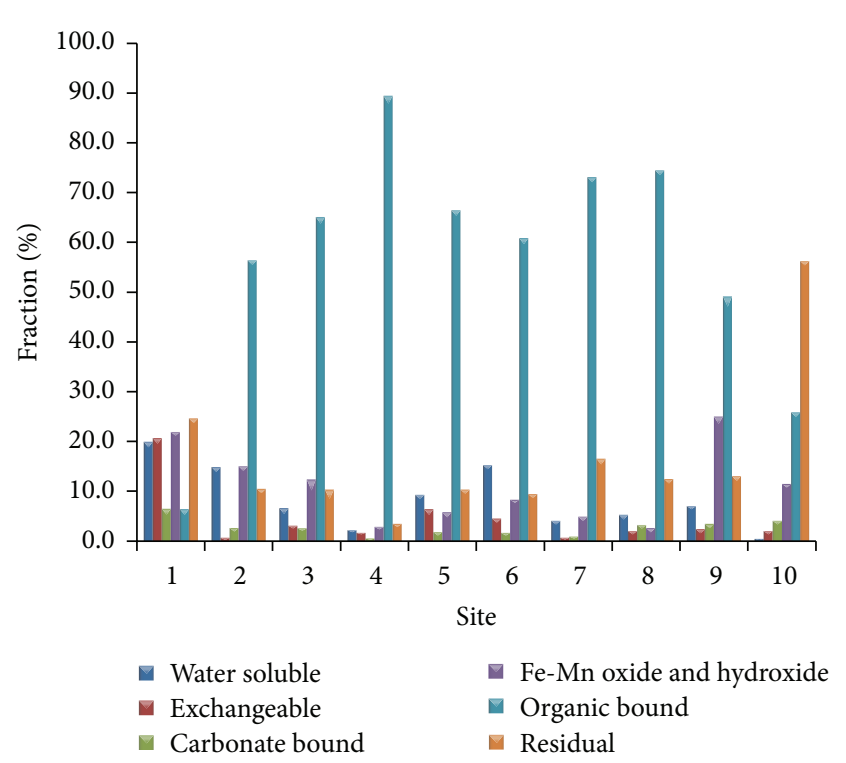

FIGURE 18: Percentage of $\mathrm{Cu}$ in each operational fraction of atmospheric particulate dust (cool and dry season).

As for $\mathrm{Zn}$, significant amount of $\mathrm{Zn}$ was associated with the residue fractions ranging from 0.96 to $87.50 \%$ across the seasons (Figures 22-25). $\mathrm{Zn}$ association with the chemically reactive fractions such as $\mathrm{Zn}$ in water soluble and exchangeable forms generally represented less than $10 \%$ of the total fractions of $\mathrm{Zn}$ in the samples. The distribution of $\mathrm{Zn}$ among the particulate dust fractions across the seasons is

cool and dry season: FVI $>$ FIV $>$ FIII $>$ FV $>$ FI $>$ FII,

hot and dry season: FVI $>$ FIV $>$ FIII $>$ FV $>$ FII $>$ FI,

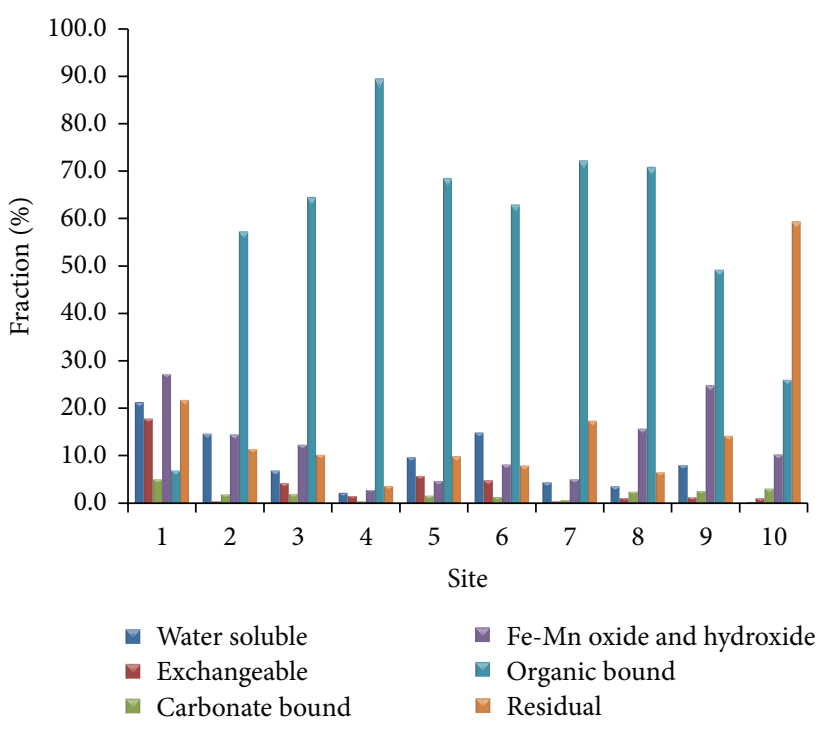

Figure 19: Percentage of $\mathrm{Cu}$ in each operational fraction of atmospheric particulate dust (hot and dry season).

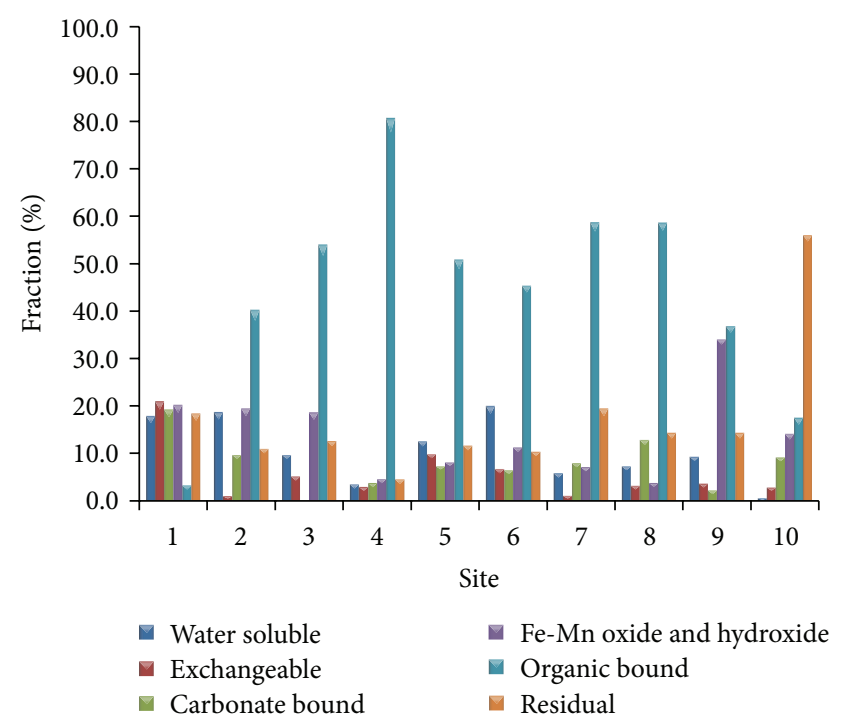

FIgURE 20: Percentage of $\mathrm{Cu}$ in each operational fraction of atmospheric particulate dust (warm and wet season).

warm and wet season: FVI $>$ FIV $>$ FIII $>$ FV $>$ FI $>$ FII,

warm and dry season: FIV $>$ FII $>$ FV $>$ FVI $>$ FII $>$ FI.

Heavy metal speciation studies are important since slight changes in metal availability and in environmental conditions can cause these elements to be toxic to animals and plants [13]. From the results presented above, $\mathrm{Cd}$ was found in its highest proportion in the form bound to Fe-Mn oxide (60.31\%) in site 3 sample. 


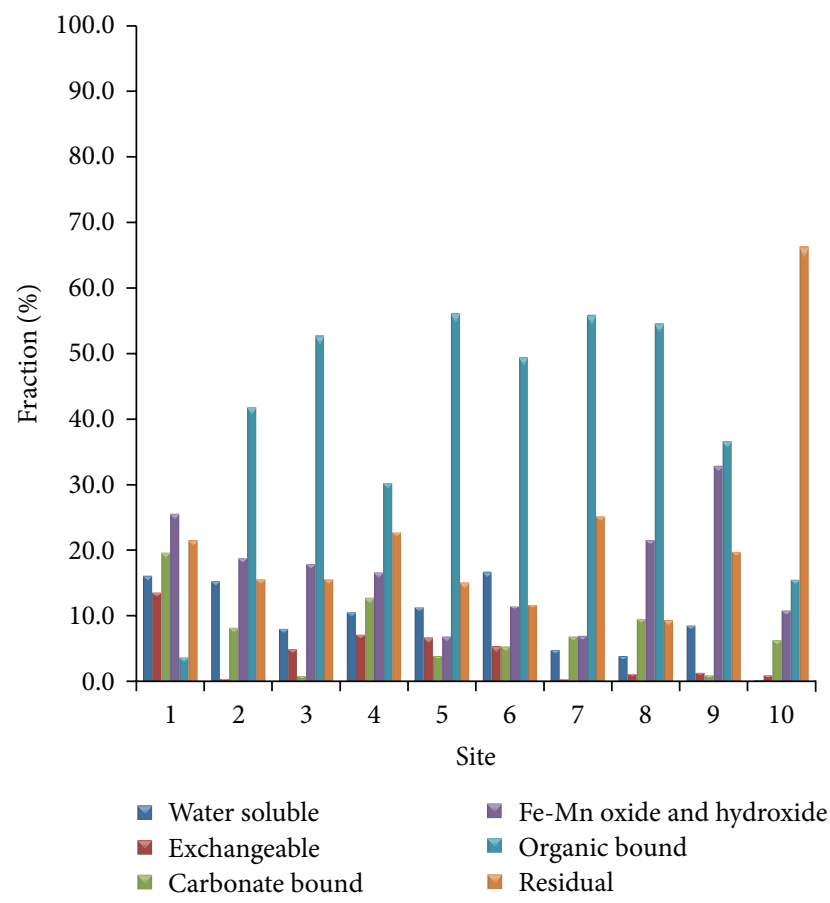

Figure 21: Percentage of $\mathrm{Cu}$ in each operational fraction of atmospheric particulate dust (warm and dry season).

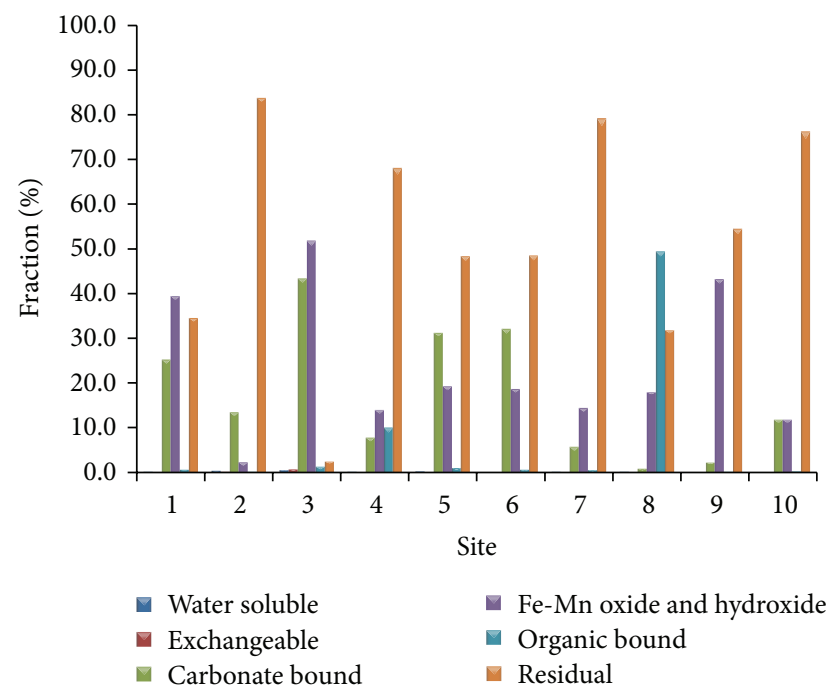

Figure 22: Percentage of $\mathrm{Zn}$ in each operational fraction of atmospheric particulate dust (cool and dry season).

The highest percentage of this fraction is relatively high and constitutes a large portion of nonresidual Cd. Heavy metals enwrapped by Fe-Mn oxides or precipitated as hydroxide have been reported by Wang et al. [14].

Metals bound to Fe-Mn oxides would be released under reductive conditions [15] and therefore are unstable under anaerobic condition. Similar to this study, Feng et al. [16] reported high percentage of $\mathrm{Cd}$ in carbonate and $\mathrm{Fe}-\mathrm{MnO}$ fractions. Also, $\mathrm{Cd}$ in samples agrees with the findings of Harrison et al. [17], Baron et al. [18], and Yusuf [19]. The high

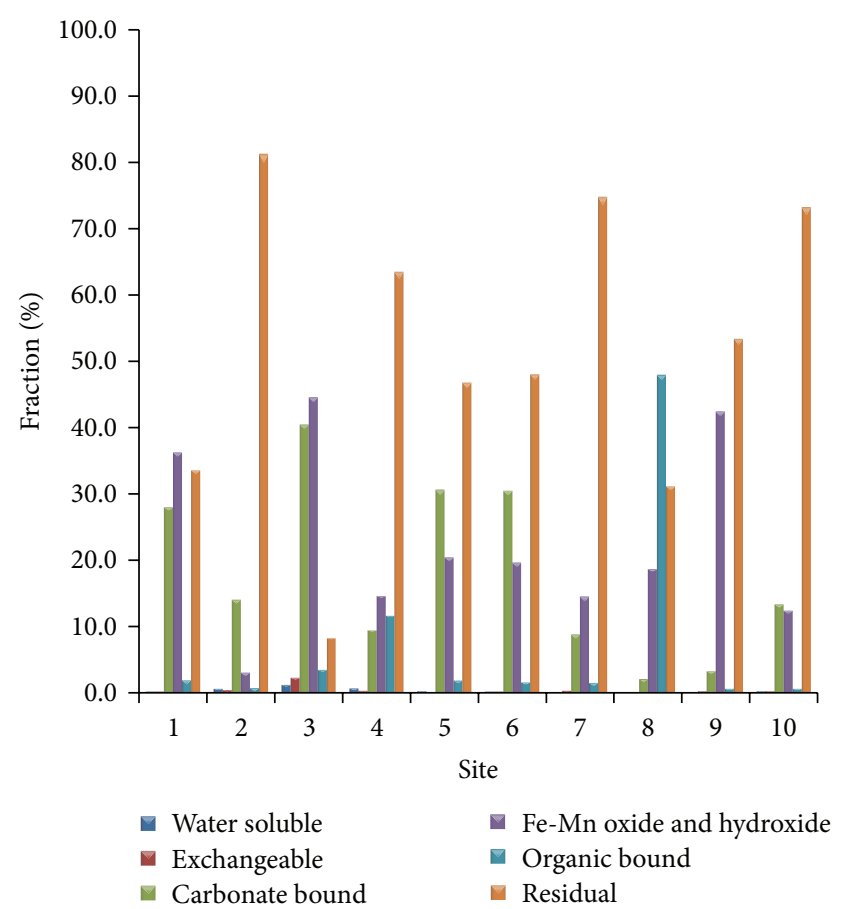

FIgURE 23: Percentage of $\mathrm{Zn}$ in each operational fraction of atmospheric particulate dust (hot and dry season).

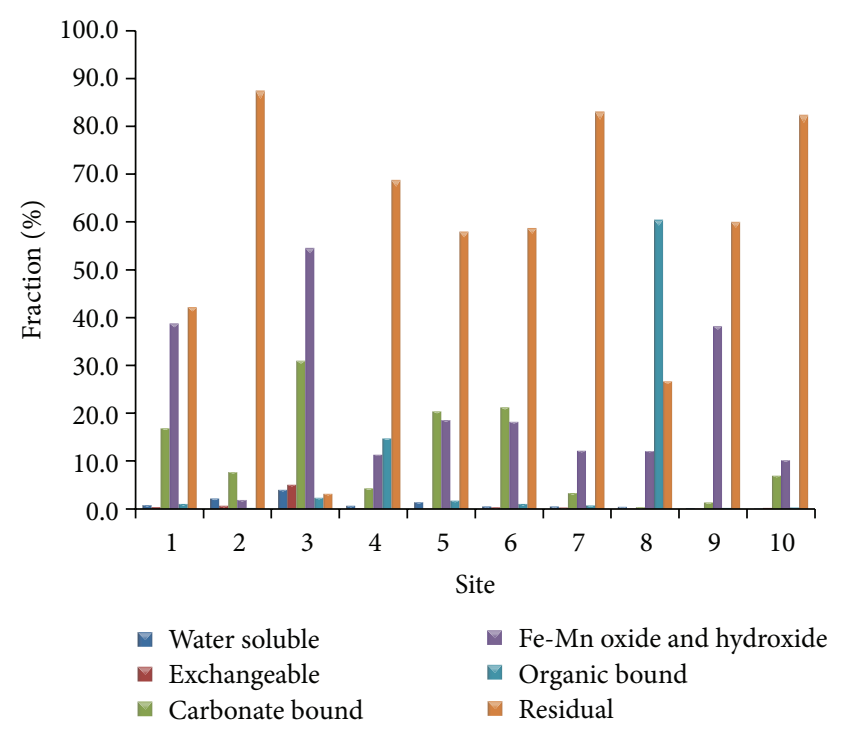

Figure 24: Percentage of $\mathrm{Zn}$ in each operational fraction of atmospheric particulate dust (warm and wet season).

amount of Cd associated with nonresidual fractions shows that it may be easily transferred into the food chain. The minor role for organic fraction in the fractionation of $\mathrm{Cd}$ in this study is consistent with the low adsorption constant of $\mathrm{Cd}$ to organic matter [20] and with evidence that $\mathrm{Cd}$ does not appear to form strong organic complexes [21].

The high percentage of $\mathrm{Cr}(31.15-84.88 \%)$ across the seasons was found in the residual fraction, indicating that 


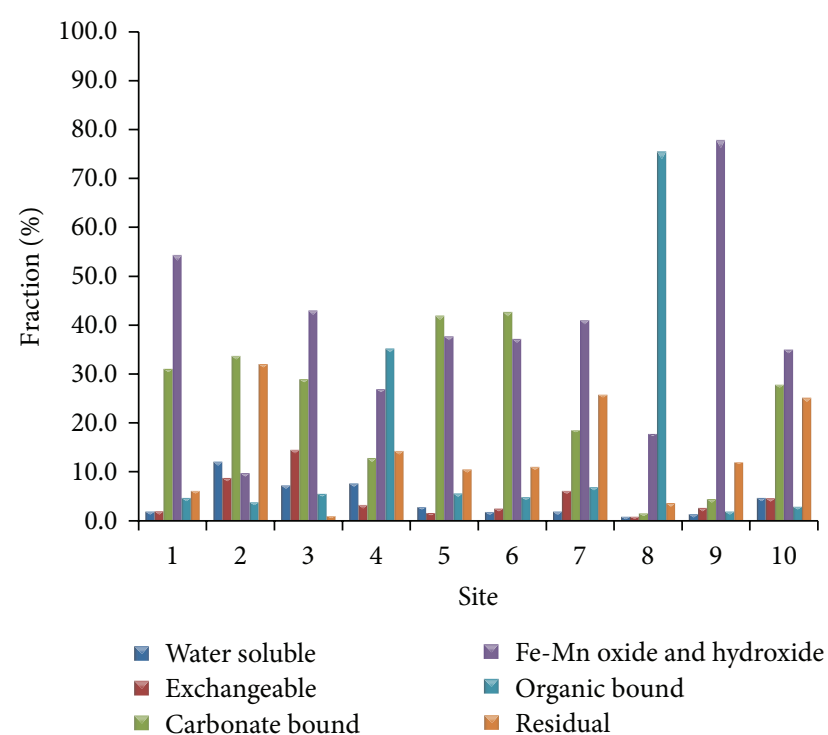

FIGURE 25: Percentage of $\mathrm{Zn}$ in each operational fraction of atmospheric particulate dust (warm and wet season).

Cr shows little risk to environment. Metal in this fraction is mainly fixed in the primary and secondary minerals [22] and is chemically stable and biologically inactive. The greater the percentage of metals present in this fraction, the smaller the risk of the metal because this portion of metal cannot be rereleased to environment under normal conditions [14]. Furthermore, the stable nature of the metal and the fact that the metal are bonded firmly within a mineral lattice restricting the bioavailability of this metal [23]. The trend in $\mathrm{Ni}$ is similar to that in $\mathrm{Ni}$ in the fact that residual fraction is the major carriers of $\mathrm{Ni}$ in the atmospheric particulate dust. Similar trend was reported by Ma and Rao [24].

In a study by Flores-Rodriguez et al. [25] on the bioavailable and stable forms of atmospheric particulate dust, Fe$\mathrm{MnO}$ and carbonate fractions of suspended solids are the most important in terms of metal binding, irrespective of heavy metal. This finding is in general agreement with the results of this study for $\mathrm{Pb}$. Studies on the fractionation of atmospheric particulate dust have suggested that $\mathrm{Pb}$ has a high affinity for carbonates [16]. As such, $\mathrm{Pb}$ is generally considered to be relatively mobile with the dust particles, primarily as a result of its small soluble component. High amount of $\mathrm{Pb}$ in the carbonate fractions is also reported in other studies on roadside soils. Howard and Sova [26] noted, for example, a larger part of $\mathrm{Pb}$ in the carbonate fraction in the most heavily contaminated roadside soil.

The predominant form of $\mathrm{Cu}$ available in the entire fraction is organic fraction. The higher stability constant of $\mathrm{Cu}$ complexes with organic matter leads to higher organic fractions. Tessier et al. [12] indicated that $\mathrm{Cu}$ exhibits the highest stability constants for most ligand among the heavy metals studied. Based on this, Ho [27] suggested that the high affinity of organic ligands with heavy metals makes $\mathrm{Cu}$ in river sediments more stable, leading to the suppression of diffusion and dispersion of $\mathrm{Cu}$; though dust samples were considered in this study, similar reasons could be responsible. However, under strong oxidizing conditions, $\mathrm{Cu}$ be leached into the environment [14]. In this fraction, the metal ion acts as the central ion, and the active organic matter group acts as the ligand or perhaps through the reaction of the sulphide ion and $\mathrm{Cu}$. The organic fraction released in this step is hardly considered very mobile or available because the $\mathrm{Cu}$ is associated with stable high-molecular weight humic substances that decompose slowly [28]. A high percentage $(3.62-89.62 \%)$ of $\mathrm{Cu}$ was found in the oxidizable fraction, indicating that high organic matter and sulphide absorbed $\mathrm{Cu}$ and played a significant role in controlling the mobilization of this element. $\mathrm{Cu}$ is usually reported to dominate in the organic and residual fractions $[17,24,29,30]$.

From the results, $\mathrm{Zn}$ fraction is considered to be occluded inside the crystalline structures and not readily available for plant absorption. The findings are different with that of Shuman [31], who reported that soil Zn was mainly associated with crystalline Fe-Mn oxide and with nonresidual extractable residual fraction, though atmospheric particulate dust was used in this study. Usero et al. [32] and Mashal et al. [33] using Tessier's method found that $\mathrm{Zn}$ is bound to residual fraction. Maskall and Thornton [34] indicate that, in contaminated soils, $\mathrm{Zn}$ is mainly found in the residual fractions. The results for atmospheric particulate dust are similar, but with less association with $\mathrm{Fe}-\mathrm{Mn}$ oxides and a higher percentage with the residual fraction. For $\mathrm{Cr}$ the residual fraction exhibited the highest percentage.

\section{Conclusion}

The atmospheric dust collected from roads in Kano Metropolis shows high concentrations of heavy metals which could lead to serious environmental hazards. Correlation analysis indicates common source of metals: $\mathrm{Zn}_{\mathrm{p}}$ and $\mathrm{Cr}$ (hot and dry season), and $\mathrm{Zn}$ : $\mathrm{Cd}$ and $\mathrm{Cr}$ (warm and wet season, and warm and dry season). The sequential extraction showed that significant amount of $\mathrm{Cd}$ was associated with carbonate and $\mathrm{Fe}-\mathrm{Mn}$ oxide fractions especially during the dry seasons. For $\mathrm{Cr}$ and $\mathrm{Ni}$ the residual fraction exhibited the highest percentage. $\mathrm{Pb}$ in the particulate dust samples is significantly associated with the carbonate bound fraction with range of $8.81-64.69 \%$ across the season. The behaviour of $\mathrm{Cu}$ is quite different from other metals in that percentage fractions are higher in the organic bound. As for Zn, significant amount was associated with the residue fractions ranging from 0.96 to $87.50 \%$ across the seasons. This study indicated that air particle pollution due to metal such as $\mathrm{Cd}$ and $\mathrm{Pb}$ may possess serious health risks to the residents in this rapidly developing and populated city.

\section{Conflict of Interests}

The authors declare that there is no conflict of interests regarding the publication of this paper.

\section{Acknowledgments}

The authors appreciate the support of Mu'azu and Khadijat both of Department of Chemistry, Kaduna State University, 
Nigeria, for analyzing the samples. Thanks are due to Mal. Ahmad Mohammed of Kano Pollution Control Unit, Kano Nigeria for his assistance especially in the field work. Members of staff of Chemistry Department of Ahmadu Bello University are also acknowledged for their immense support given to realization of this project.

\section{References}

[1] S.-H. Cho, H. Tong, J. K. McGee, R. W. Baldauf, Q. T. Krantz, and M. I. Gilmour, "Comparative toxicity of size-fractionated airborne particulate matter collected at different distances from an urban highway," Environmental Health Perspectives, vol. 117, no. 11, pp. 1682-1689, 2009.

[2] J. Edwards, S. Walters, and R. K. Griffiths, "Hospital admissions for asthma in preschool children: relationship to major roads in Birmingham, United Kingdom," Archives of Environmental Health, vol. 49, no. 4, pp. 223-227, 1994.

[3] A. J. Venn, S. A. Lewis, M. Cooper, R. Hubbard, and J. Britton, "Living near a main road and the risk of wheezing illness in children," American Journal of Respiratory and Critical Care Medicine, vol. 164, no. 12, pp. 2177-2180, 2001.

[4] A. O. Ogunfowokan, O. I. Asubiojo, A. A. Adeniyi, and E. A. Oluyemi, "Trace lead, zinc and copper levels in Barbula lambarenensis as a monitor of local atmospheric pollution in IleIfe, Nigeria," Journal of Applied Sciences, vol. 4, no. 3, pp. 380$383,2004$.

[5] H. J. Annergarn, S. J. Moja, J. Malahela, P. Kgashane, and B. de Lange, "Vanderbijlpark-Golden highway project: dust fall-out monitoring report," AER 22.178S_GHP, 2002.

[6] A. O. Ogunfowokan, J. A. O. Oyekunle, L. M. Durosinmi, A. I. Akinjokun, and O. D. Gabriel, "Speciation study of lead and manganese in roadside dusts from major roads in Ile-Ife, South Western Nigeria," Chemistry and Ecology, vol. 25, no. 6, pp. 405415, 2009.

[7] O. O. Faboya, "Industrial pollution and waste management," in Dimensions of Environmental Problems in Nigeria, A. Osuntokun, Ed., pp. 26-35, Ibadan Davidson Press, Ibadan, Nigeria, 1997.

[8] G. Nabuloa, "Assessment of heavy metal contaimination of food crops and vegetables from motor vehicle emission in Kampala City Uganda," A technical report submitted to IDRC-Agropolis. Idrinfo Idc. Ca/archieve/cordocs/119964/AGROPLISTECHRPT, 2004.

[9] O. J. Okunola, A. Uzairu, C. E. Gimba, and J. A. Kagbu, "Metals in roadside soils of different grain sizes from high traffic roads in Kano metropolis, Nigeria," Toxicological and Environmental Chemistry, vol. 93, no. 8, pp. 1572-1590, 2011.

[10] M. Adnan, A. Foras, and J. Qasem, "Determination of cadmium and lead in different cigarette brands in Jordan," Acta Chimica Slovenica, vol. 50, pp. 375-381, 2003.

[11] N. Finžgar, P. Tlustoš, and D. Leštan, "Relationship of soil properties to fractionation, bioavailability and mobility of lead and zinc in soil," Plant, Soil and Environment, vol. 53, no. 5, pp. 225-238, 2007.

[12] A. Tessier, P. G. C. Campbell, and M. Blsson, "Sequential extraction procedure for the speciation of particulate trace metals," Analytical Chemistry, vol. 51, no. 7, pp. 844-851, 1979.

[13] K. M. Banat, F. M. Howari, and A. A. Al-Hamad, "Heavy metals in urban soils of central Jordan: should we worry about their environmental risks?" Environmental Research, vol. 97, no. 3, pp. 258-273, 2005.
[14] L. Wang, R. Yu, G. Hu, and X. Tu, "Speciation and assessment of heavy metals in surface sediments of Jinjiang River tidal reach, Southeast of China," Environmental Monitoring and Assessment, vol. 165, no. 1-4, pp. 491-499, 2010.

[15] A. K. Singh, S. I. Hasnain, and D. K. Banerjee, "Grain size and geochemical partitioning of heavy metals in sediments of the Damodar River-a tributary of the lower Ganga, India," Environmental Geology, vol. 39, no. 1, pp. 90-98, 1999.

[16] X. D. Feng, Z. Dang, W. L. Huang, and C. Yang, "Chemical speciation of fine particle bound trace metals," International Journal of Environmental Science \& Technology, vol. 6, no. 3, pp. 337-346, 2009.

[17] R. M. Harrison, D. P. H. Laxen, and S. J. Wilson, "Chemical associations of lead, cadmium, copper, and zinc in street dusts and roadside soils," Environmental Science and Technology, vol. 15, no. 11, pp. 1378-1383, 1981.

[18] J. Baron, M. Legret, and M. Astruc, "Study of interactions between heavy metals and sewage sludges. Determination of stability constants and complexation capacities of complexes formed with $\mathrm{Cu}$ and Cd," Environmental Technology, vol. 11, no. 2, pp. 151-162, 1990.

[19] K. A. Yusuf, "Sequential extraction of $\mathrm{Pb}, \mathrm{Cu}, \mathrm{Cd}$ and $\mathrm{Zn}$ in soils near Ojota waste site," Journal of Agronomy, vol. 6, no. 2, pp. 331337, 2007.

[20] A. Chlopecka, J. R. Bacon, M. J. Wilson, and J. Kay, "Forms of cadmium, lead, and zinc in contaminated soils from Southwest Poland," Journal of Environmental Quality, vol. 25, no. 1, pp. 6979, 1996.

[21] G. Sposito, L. J. Lund, and A. C. Chang, "Trace metal chemistry in arid-zone field soils amended with sewage sludge: I. Fractionation of $\mathrm{Ni}, \mathrm{Cu}, \mathrm{Zn}, \mathrm{Cd}$, and $\mathrm{Pb}$ in solid phases," Soil Science Society of America Journal, vol. 46, no. 2, pp. 260-264, 1982.

[22] P. Wu, C. Q. Liu, G. P. Zhang, and Y. G. Yang, "Chemical forms and ecological risks of heavy metals in river sediment at carbonatite mining area," Rural Eco-Environment, vol. 20, no. 3, pp. 28-31, 2004.

[23] P. P. Coetzee, "Determination and speciation of heavy metals in sediments of the Hartbeespoort Dam by sequential chemical extraction," Water SA, vol. 19, no. 4, pp. 291-300, 1993.

[24] L. Q. Ma and G. N. Rao, "Chemical fractionation of cadmium, copper, nickel, and zinc in contaminated soils," Journal of Environmental Quality, vol. 26, no. 1, pp. 259-264, 1997.

[25] J. Flores-Rodriguez, A. L. Bussy, and D. R. Thevenot, "Toxic metals in urban runoff: physico-chemical mobility assessment using speciation schemes," Water Science and Technology, vol. 29, pp. 83-93, 1994.

[26] J. L. Howard and J. E. Sova, "Sequential extraction analysis of lead in Michigan roadside soils: mobilization in the vadose zone by deicing salt," Journal of Soil Contamination, vol. 2, pp. 361$378,1993$.

[27] T. L. T. Ho, Heavy metal pollution of agricultural soil and river sediment in Hanoi Vietnam [Ph.D. thesis], Kyushu University, Fukuoka, Japan, 2000.

[28] S. P. Singh, F. M. Tack, and M. G. Verloo, "Heavy metal fractionation and extractability in dredged sediment derived surface soils," Water, Air, and Soil Pollution, vol. 102, no. 3-4, pp. 313-328, 1998.

[29] R. S. D. Hamilton, D. M. Revitt, and R. S. Warren, "Levels and physico-chemical associations of $\mathrm{Cd}, \mathrm{Cu}, \mathrm{Pb}$ and $\mathrm{Zn}$ in road sediments," Science of the Total Environment, vol. 33, no. 1-4, pp. 59-74, 1984. 
[30] L. Ramos, L. M. Hernandez, and M. J. Gonzalez, "Sequential fractionation of copper, lead, cadmium and zinc in soils from or near Donana National Park," Journal of Environmental Quality, vol. 23, no. 1, pp. 50-57, 1994.

[31] L. M. Shuman, "Fractionation method for soil microelements," Soil Science, vol. 140, no. 1, pp. 11-22, 1985.

[32] J. Usero, M. Gamero, J. Morillo, and I. Gracia, "Comparative study of three sequential extraction procedures for metals in marine sediments," Environment International, vol. 24, no. 4, pp. 487-496, 1998.

[33] K. Mashal, M. Al-Qinna, and A. Yahya, "Spatial distribution and environmental implication of lead and zinc in urban soils and street dust samples in Al-Hashimeyeh municipality," Jordan Journal of Mechanical and Industrial Engineering, vol. 3, no. 2, pp. 141-150, 2009.

[34] J. E. Maskall and I. Thornton, "Chemical partitioning of heavy metals in soils, clays and rocks at historical lead smelting sites," Water, Air, and Soil Pollution, vol. 108, no. 3-4, pp. 391-409, 1998. 

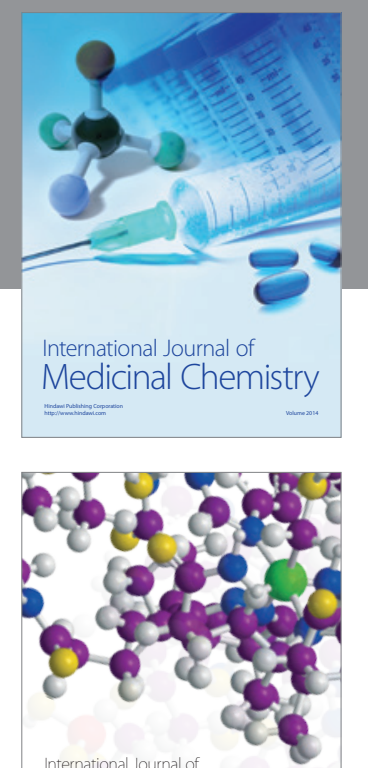

\section{Carbohydrate} Chemistry

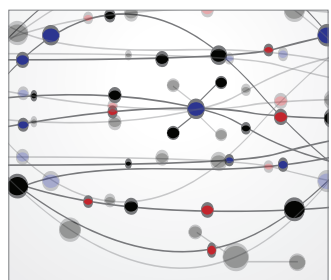

The Scientific World Journal
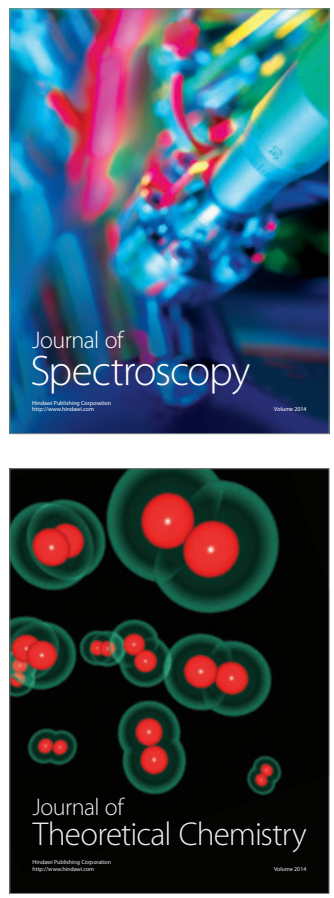
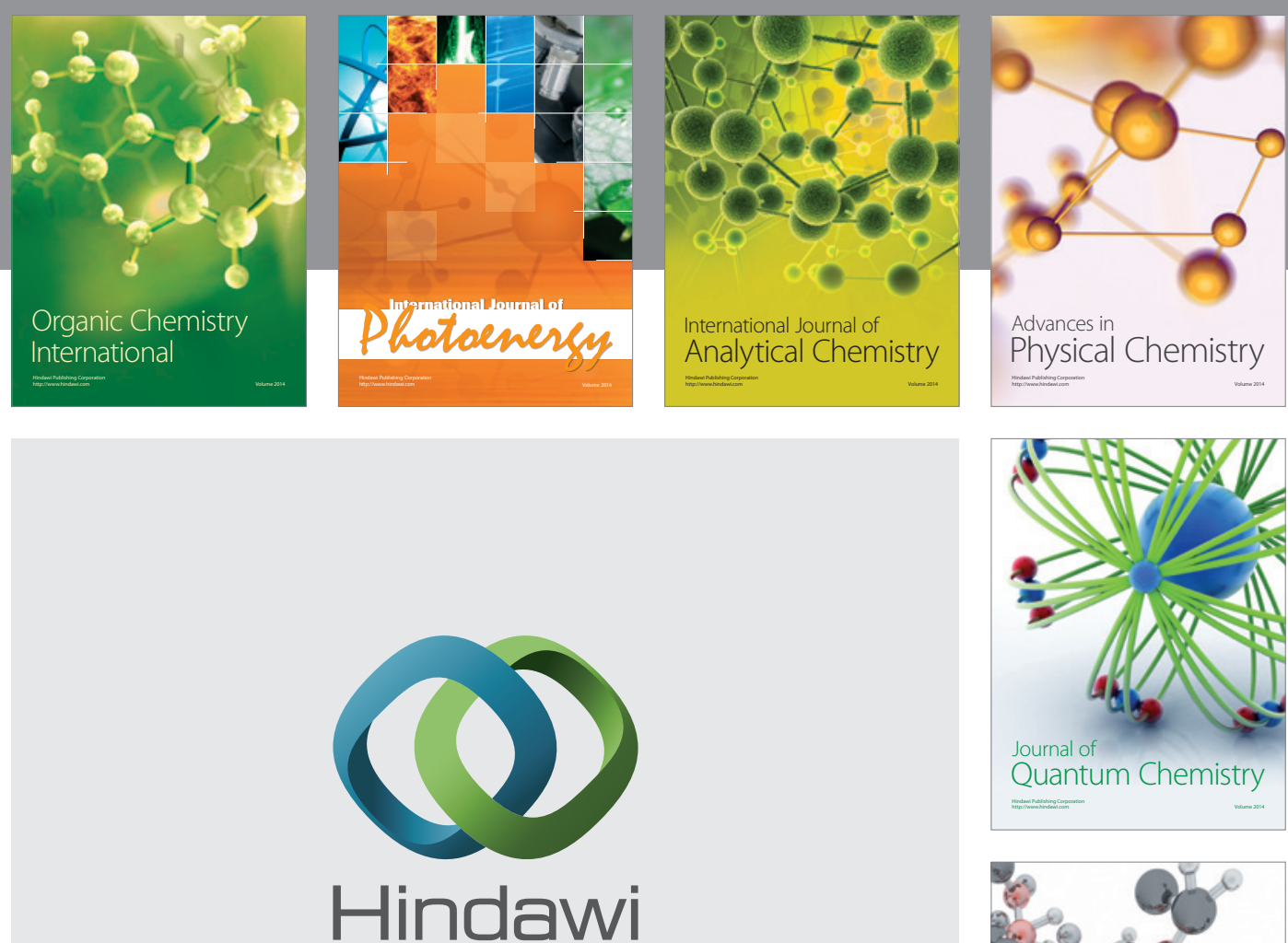

Submit your manuscripts at

http://www.hindawi.com

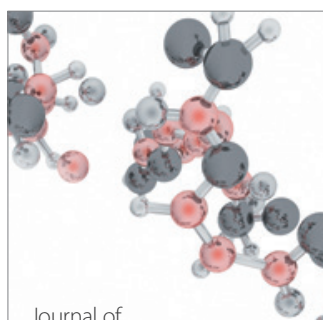

Analytical Methods

in Chemistry

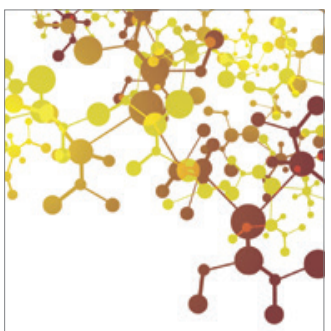

Journal of

Applied Chemistry

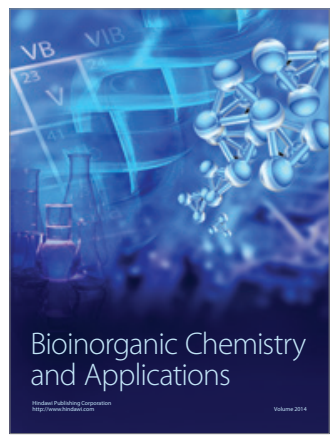

Inorganic Chemistry
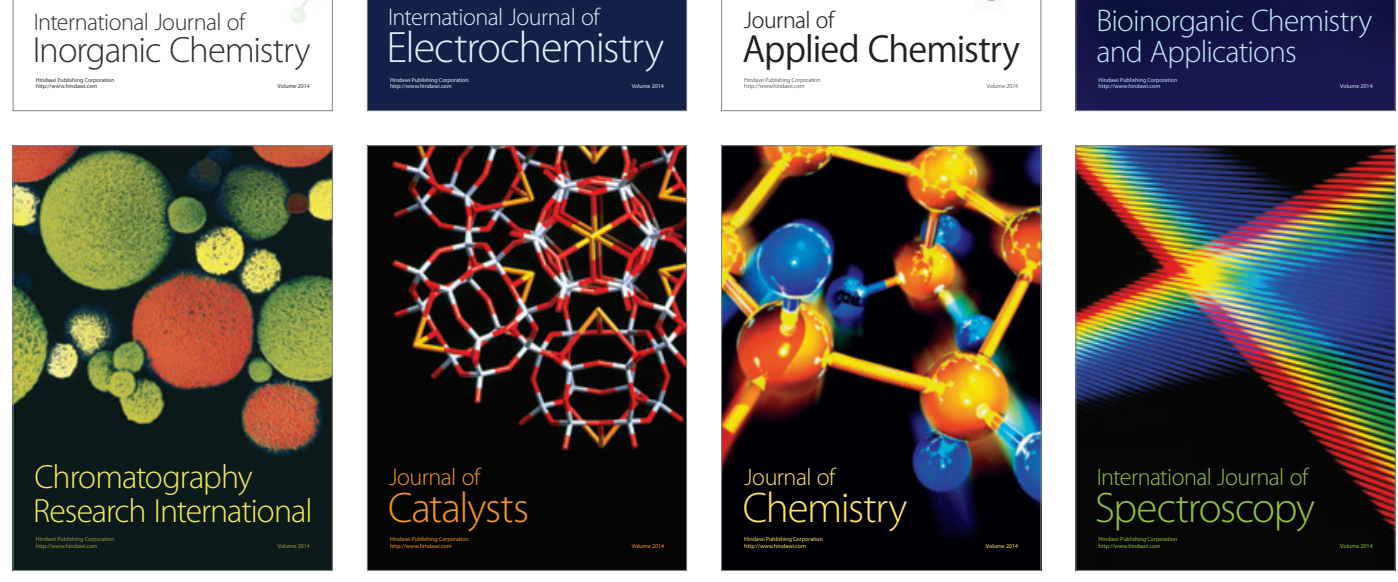